\title{
Rethinking Access: How Humanitarian Technology Blurs Control and Care
}

DOI:

10.1111/disa. 12333

\section{Document Version}

Accepted author manuscript

Link to publication record in Manchester Research Explorer

\section{Citation for published version (APA):}

Fast, L., \& Jacobsen, K. L. (2019). Rethinking Access: How Humanitarian Technology Blurs Control and Care. Disasters, 43(S2), S151-S168. https://doi.org/10.1111/disa.12333

\section{Published in:}

Disasters

\section{Citing this paper}

Please note that where the full-text provided on Manchester Research Explorer is the Author Accepted Manuscript or Proof version this may differ from the final Published version. If citing, it is advised that you check and use the publisher's definitive version.

\section{General rights}

Copyright and moral rights for the publications made accessible in the Research Explorer are retained by the authors and/or other copyright owners and it is a condition of accessing publications that users recognise and abide by the legal requirements associated with these rights.

\section{Takedown policy}

If you believe that this document breaches copyright please refer to the University of Manchester's Takedown Procedures [http://man.ac.uk/04Y6Bo] or contact uml.scholarlycommunications@manchester.ac.uk providing relevant details, so we can investigate your claim.

\section{OPEN ACCESS}




\section{Rethinking Access: how humanitarian technology governance blurs control and care}

Published in Disasters 43 (S2): S151-168. 2019.

Katja Lindskov Jacobsen and Larissa Fast

Despite the importance attached to the humanitarian uses of new digital technology, surprisingly little attention is paid to the role of digital technology and related forms of data production, storage, processing, and sharing in humanitarian governance. We use Barnett's conceptualisation of humanitarian governance when arguing for a more sustained engagement about the role of new technology in the literature on humanitarian governance. Specifically, we propose a shift from thinking of humanitarian governance through technology to a two-fold alertness to governance of (a) the production of new technology (emergence) and (b) that which is produced by digital technologies (constitutive effects), as used in humanitarian contexts. This conceptualisation of the role of digital technology in humanitarian governance elucidates important issues, including that of access to digitalised data collected from humanitarian subjects, with implications for their (in) security. Reflecting on the meaning of humanitarian governance in the context of the production of digital recipient bodies, we conclude by suggesting that access is no longer 'only' about challenges of gaining access to vulnerable populations (e.g. in 'non-permissive' environments, such as Syria), but about challenges of preventing access to vulnerable digital bodies and their use for aggressive purposes. In short, access and protection acquire a new dimension and, to appreciate that, analyses of humanitarian governance must be more attentive to the role of digital technology.

Keywords: agentic capacity, digitalised data, digitalised recipient bodies, digital technology, humanitarian access, humanitarian technology governance, vile bodies 


\section{Introduction}

The growth and expansion of humanitarian action has resulted in calls to investigate the structures and practices that govern 'humanitarianism', and the world that such governance produces. Accordingly, various scholars have asked questions about humanitarian governance: about its genesis and genealogy (Lester and Dussart, 2014), the relationship between humanitarian governance and the expansion of imperialism (Mitchell, 2017), the structure of international humanitarianism and the resulting possibilities for sectoral change and reform (Bennett, Foley, and Pantuliano, 2016; Kent et al., 2016; Knox-Clarke, 2017), or specific forms of humanitarian governance that emerge in specific countries and related compositions of actors (Lautze, RavenRoberts, and Erkineh, 2009). A particularly useful and comprehensive dissection of the notion and elements of humanitarian governance appears in Michael Barnett's article, 'Humanitarian governance' (2013). For him, humanitarian governance refers to efforts to 'secure the welfare of the population, the improvement of its condition, the increase of its wealth, longevity, health' (Foucault, cited in Barnett, 2013, p. 381), and 'the administration of human collectivities in the name of a higher moral principle that sees the preservation of life and the alleviation of suffering as the highest value of action' (Fassin, cited in Barnett, 2013, p. 381).

More specifically, Barnett (2013) lays out six sets of key questions. The first two relate to the purpose and growth of the humanitarian sector, and the world it seeks to create. Third, he advocates an examination of who shows up at humanitarian crises, an approach which allows for a more inclusive view of the sector. This view encompasses the 'new actors', such as diaspora groups, faith-based actors, the private sector, and social technology groups, all of which fall beyond the traditional and narrowly defined set of international NGOs and westerns donors that for years dominated the analysis of the humanitarian sector. The fourth and fifth set of questions focus on organisation and accomplishments as well as the techniques of governance. Finally, the question of authority emerges, specifically related to the different authorities that humanitarians possess and how they manage these authorities.

In this article, we engage with Barnett's notion of humanitarian governance. He widens the analysis beyond traditional political science to include critical theory perspectives on the practices, discourses, and dispositions of humanitarianism. We share this view but take it one step further. While a useful starting point for the deconstruction of humanitarian governance more broadly, we argue that this framing fails to adequately account for one of the most prominent contemporary trends: the role of technology, notably digital technology and related forms of data, as these are increasingly taken up by various humanitarian actors in their efforts towards the 'global governance of humanity' (Barnett, 2013, p. 379). Similarly, for the question of authority, more explicit attention to the role of digital technology and related forms of digital data is key to enable consideration of, and possible changes to, for example, the distribution of violence that underwrites the making of authority. This is not a rejection, but rather a further development of Barnett's framework. For instance, where he asks who shows up at humanitarian crises, we suggest that it is also crucial to similarly ask what technologies 'show up' in the context of humanitarian crisis - and what 
additional governance issues emerge. This proposed conceptualisation of the role of digital technology and related forms of data in humanitarian governance conform to the suggestion that 'technology' is not neutral but represents a form of power that blurs care and control (Barnett, 2011; Malkki, 1996; Scott-Smith, 2015a).

Scholars are devoting increased attention to the uses of new digital technology and related forms of data in humanitarian practice. Indeed, humanitarian actors - from UN agencies to NGOs-have increasingly turned to digital technologies with, for example, biometrics (Jacobsen, 2015a, 2015b), drones (Sandvik and Lohne, 2014), remote sensing and programming (Duffield, 2016; Andersson and Weigand, 2015), satellite imagery (Witjes and Olbrich, 2015), digital mapping (Givoni, 2016), and the attendant forms of digital data (McDonald, 2016; Fast, 2017; Read, 2016; Burns, 2014). One important factor that has framed and driven the humanitarian turn to digital technologies and data is the discourse within the humanitarian sector, which construes these new technologies as empowering (OCHA, 2013; IFRC, 2013) and as 'game-changers' (Meier, 2015) that can help overcome new as well as longstanding humanitarian challenges. Indeed, there has been a tendency to view technological innovation in utopian terms (Sandvik et al., 2014; Jumbert and Sandvik, 2017; Jacobsen, 2015b). In other words, we are seeing an uptake of new digital technology in an increasing range of humanitarian contexts (refugee registration, food aid, vaccination programmes, etc.) - a development that has already dramatically transformed, and will continue to transform, humanitarian governance. ${ }^{1}$

This rich scholarship has demonstrated various implications of this digital turn. This article adds a focus on governance of the uses of these technologies and the digitalised beneficiary data that get produced, and, finally, it ties these insights back to a longstanding and vital humanitarian challenge, namely that of access. Aid agencies' access 'to' affected populations or affected populations' access to services and protection are both still key dimensions of access, as evident from for example Syria and South Sudan. However, adding to this, a reversal of access becomes visible once we include a focus on technology in our analysis of humanitarian governance. That is, with the production, storage, and processing of increasing amounts of sensitive digitalised data of humanitarian beneficiaries comes a third dimension: access to data and the concomitant question of how to prevent access to these data by (nefarious) actors whose uses may undermine rather than buttress the security of these digitalised humanitarian subjects.

To illustrate the important role of technology in humanitarian governance this article accomplishes two tasks. First, it makes a conceptual contribution by showing how insights from Jasanoff (2004a, 2004b) and Chamayou (2008, 2012) can be developed into a framework that shifts from thinking of humanitarian governance through technology to a two-fold alertness to governance of (a) the uses of new technology and (b) that which is produced by digital technologies. Second, it offers examples of the kinds of governance issues that such a conceptualisation will enable us to grasp, including the kinds of risks that will enhance our ability to protect humanitarian subjects, in our analyses of contemporary humanitarian governance. Making these visible also illustrates what we 
will fail to appreciate if we conceptualise humanitarian governance in a manner that pays insufficient attention to the roles and functions of technology and data.

\section{Conceptual framing}

A belief in better governance through technology depends on the assumption that technology and data are simply 'means to an end'; for humanitarians, this encompasses technology as a 'means' to improve humanitarian protection, food delivery, or refugee registration. Put differently, in the humanitarian domain, technology is commonly understood as a set of tools that make it easier and more efficient to achieve a set of predefined goals (Harvard Humanitarian Initiative, 2011; IFRC, 2013; Read, Taithe, and Mac Ginty, 2016; Jacobsen, 2015b). In other words, technology or data are seen as 'neutral'. Given the inability of such conceptualisations to account for important aspects of contemporary humanitarian governance, we propose instead to begin our analysis from a conception of technology as capable of 'agentic capacity' (Coole, 2013) and of generating constitutive effects that we need to factor in when thinking about the role of technology in humanitarian governance. Accordingly, in an effort to develop an analytical framework more attuned to the politics of humanitarian technology governance, we combine Grégoire Chamayou's insights about 'vile bodies' and experimentation with insights from Science and Technology Studies (STS) (notably Sheila Jasanoff) and the more recent humanitarian materiality literature (Redfield, 2012; Scott-Smith, 2015a, 2015b). We aim, by combining these insights, to provide an analytical framework through which to unpack processes and productive effects at the stages where technology and data enable an expansion of governance (control) and concurrent questions about how best to guard this accessibility against the risk that arises when or if these data would be used for other purposes than humanitarian protection. We suggest that these two analytical levels offer a fruitful framing for exploring these otherwise underappreciated aspects of humanitarian technology governance: governance of humanitarian technology use and governance of what these sociotechnical assemblages (humanitarian practices, discourses, and materiality's constitutive agentic capacity) produce.

Put differently, with the analytical framework proposed below, we call attention to two ways in which humanitarian technology can do harm, and, accordingly two areas about which the issue of governance of - and not simply through — technology must be attended to carefully in order to understand the implications for the protection of the humanitarian subject.

\section{A) Governance of humanitarian technology use: using 'vile bodies' as test subjects}

French philosopher Grégoire Chamayou (2008) has written a Foucault-inspired account of the history of medical experimentation on what he terms 'vile' bodies, or those bodies to which society accords lesser value, such as slaves, orphans, or prisoners (Lambert, 2013; Jacobsen, 2015b). According to Chamayou, throughout history medical practices have collaborated in the production of vile bodies suited for experimentation. These bodies serve an important function, not only in the making of new types of medical interventions but also, importantly, in enabling a shift in the mode of sovereign power. Indeed, it is in his attention to this link to modes of sovereign power that Chamayou's analysis differs from other contributions to the history of medical experimentation on 
vile bodies. ${ }^{2}$ By introducing this notion, Chamayou calls attention to the underlying justification mechanisms whereby it becomes possible to consider specific bodies 'suitable' for experimentation - namely through their determination as vile. ${ }^{3}$ Specifically, Chamayou develops 'a typology of vilization technologies' (Lambert, 2013), which can be understood as a typology of technologies involved in the production of bodies considered 'fit' for experimentation - whether because these bodies are constructed as vile or undesirable (Agier, 2010), surplus (Duffield, 2007), or simply as less valuable (Fassin, 2010). Critically, then, the question is how humanitarian subjects may in certain contexts come to be determined as 'vile', which justifies their subjection to experiments with new technologies — not only medical but also, as we shall illustrate and as others have shown (Sandvik, Jacobsen, and McDonald, 2017), experiments with new digital technologies. Insofar as this occurs, it is a crucial dimension of humanitarian governance-more specifically, of the governance of risks and violence where such production of vile bodies and related practices of experimentation unfold in humanitarian contexts.

Concerning the question of how the production of vile bodies and their subsequent subjection to experiments plays a vital role in establishing and reproducing relationships of power and domination, Chamayou develops this argument further in a later book, Manhunts (2010, translated into English in 2012). In Manhunts, Chamayou shows how, throughout history, the exercise of power and domination has been intimately linked not only to the production of seemingly authoritative and unyielding 'truths', but also to an underlying 'manhunt', 'which has been key to the incessant emergence of new forms of domination. To write the history of manhunts is also 'to write the history of the technologies of predation indispensable for the establishment and production of relationships of domination' (Chamayou, 2012, p.1).

From 'vile' bodies to humanitarian governance of technology emergence

This account of the role of experimentation opens an important line of inquiry into the relationship between humanitarian technology and the issue of governance, primarily through the use of experimental technologies and data in the humanitarian sphere and the harm their use may produce. Chamayou's account of experimentation and the emergence of new technologies of power highlights the importance of exploring how humanitarian technology governance might serve a similar role, entangled in the production of bodies deemed 'fit' for experimentation and for the trialling of technologies that may enable a shift in the mode of sovereign power. Importantly, Chamayou's analysis urges consideration of the question of power and experimentation on peripheral/superior bodies in a manner that attends to how these practices are both discursive and physical, meaning attention to material dimensions and the role of discourse. In other words, this first aspect of humanitarian technology governance focuses on 'technology emergence' and attendant practices of experimentation, including attention to the possible emergence of harmful side effects and subordinate subject positions. Looking to the domain of medicine offers ample evidence of how technology testing has unfolded in humanitarian settings and how these practices can come with harmful—sometimes even fatal—side effects (Shah, 2006). Scholars have documented how, in the colonial periphery, various new medical technologies (including vaccination techniques) have been tested in experiments that exposed colonial subjects to 
insecurities and harmful side effects (Petryna, 2005, 2009). Looking at experimental uses of new technology in contemporary humanitarian settings, we see trials of unapproved medical innovations as well as testing of a range of technological innovations, from piloting of mobile health platforms (Tomlinson et al., 2013) to trials of 'fortified blended foods' (Scott-Smith, 2015a, 2015b), genetically modified foods, and other biometric technologies (Jacobsen, 2015a, 2015b). These interventions are often justified on the basis of improvements in 'care', even as their effectiveness is often mixed. For example, the proliferation of mobile health (mHealth) technology pilots in Uganda eventually caused the Ugandan government to call a moratorium on pilot projects in the country. Not only were such projects entirely distinct, creating many new health platforms that were incompatible across agencies, sectors, and locations, their overall effectiveness remains questionable (Tomlinson et al., 2013). This proliferation of pilot programmes exemplifies an ability to test new technologies in places where governance of new technologies may be less regulated or codified, whereas in western countries such practices of care would likely be controlledgoverned-more closely.

This legacy underlines the importance of examining how the use of humanitarian settings to test new technology depends upon and reinforces the production of an 'enabling' condition, and how this constitutes an overlooked example of humanitarian governance as a form of power that blurs care and control, since these practices of care are also constitutive of subordinate subject categories. Importantly, the constitution of humanitarian subjects of care and subordination, in turn, enables the acceptability of humanitarian technology experimentation, with implications for the distribution of security/insecurity of technology emergence. Such critical questioning is crucial to probing the possibility of side effects and harms that result from 'experimental' humanitarian technology use.

\section{Technology emergence: how care and control intertwine}

This line of inquiry calls attention to another sense in which 'humanitarian technology governance' is a form of power that blurs control and care, emancipation, and domination. In this process, subjects are being 'cared for' and at the same time dominated, through subordinate subject positions. This then allows for and accepts that the safety of humanitarian subjects becomes subservient to the aim of making new technologies 'safe' for use by more 'valuable citizens' through these experiments. The focus on how care and control intertwine at the level of technology emergence in humanitarian contexts is important as it illuminates otherwise underappreciated dimensions of power in the context of humanitarian technology governance. First, it calls attention to the risk of harmful side effects and the constitution of 'subjects fit for experimentation'including a certain distribution of harm/safety. Barnett's conception of humanitarian governance is helpful, but in considering the use of new technologies we find it crucial to pay explicit attention to the related governance effect of humanitarian technology. Thus, asking critical questions about how specific humanitarian technology uses are linked to the constitution of categories, with implications for the blurring of care and control in the context of humanitarian technology governance (Barnett, 2011; Malkki, 1996; Feldman and Ticktin, 2010). We therefore propose a framework that explicitly focuses on how, in humanitarian technology and data governance, various processes and practices feed into the constitution of humanitarian subjects as suitable test subjects - and on the distribution 
of security/insecurity that materialises when experimental humanitarian technology uses expose these subjects to insecurities, and from which other, more valuable bodies, are spared. With an expansion of technologies that are tested in 'distant' zones, governance effects are therefore expanded, including the constitution of categories of domination (subordinate subject positions) with potentially harmful implications for the kinds of insecurity to which humanitarian subjects (unable to reject this positioning as 'guinea pigs') are at risk of being exposed.

\section{B) Governance of what humanitarian technology produces}

To appreciate an additional set of governance effects, we must pay attention to how technology can have constitutive effects. Specifically, we suggest that the STS notion of co-production is helpful in calling attention to two types of constitutive processes: the production of technology in a certain capacity (as reliable or authoritative) and constitution by technology. Technology is not simply a passive means through which to achieve predefined ends. One sense in which technology is political stems from its agentic capacity (Coole, 2013; Bennett, 2010; Latour, 1996); that is, from the ways in which technology has a capacity to effect change and, as Sheila Jasanoff (2004a) puts it, influences the making of social order and social identity. Here the focus is on the ability of technology, or rather 'sociotechnical formations', to 'loop back' and influence how we see the world and our role in it (Jasanoff, 2004a, p. 2; 2005). This may occur either because new technology reinforces existing structures of inequality or because new technology makes it possible to conceive of additional aspects of human existence as accessible, knowable, or relevant to the determination of subject categories (e.g., as valuable or of little worth, as safe or unsafe). Without an appreciation of such effects, we fail to appreciate how humanitarian technology alters conceptions of the aspects of human life considered governable.

To illustrate the point, the introduction of biometric technology and the existence of digitalised biometric refugee data makes it possible to think about the digital refugee body as vitally important to the determination of refugee identity, including the demarcation of safe versus unsafe or 'legitimate' versus 'illegitimate' refugees. Indeed, biometric technology was able to influence the constitution of a new type of refugee body, namely the 'digital refugee'. In another example, the expansion and integration of cash transfers to Syrian refugees in Lebanon grants refugees faster, more secure, and more dignified ways to access assistance. Yet it also grants aid agencies and donors access to vast amounts of data about the habits of refugees, and requires refugees to register in order to qualify (Parker, 2016). In these examples, humanitarian uses of digital technologies loop back in ways that blur care and control; the digital refugee is being 'cared for' at the same time as new dimensions of refugee existence are rendered 'governable' and open to new forms of control, thus altering traditional political ontologies and boundaries. The digital refugee is simultaneously cared for and exposed to new forms of insecurity and harm.

\section{From 'co-production' to governance in the context of the constitutive effects of technology}

Accordingly, it is important to explore the constitutive processes through which new technologies are established as politically relevant-for example, as an authoritative source of politically relevant knowledge. Thus, another dimension of humanitarian technology governance concerns how using 
humanitarian technology contributes to their acceptability and bolsters their potential governance effects beyond the humanitarian setting. Pointing out how an otherwise controversial technology has been used for humanitarian purposes can contribute to making this technology more acceptable.

Without attention to these two aspects of humanitarian technology - that is, emergence and constitutive effects - the risk exists that humanitarianism's embrace of new digital technology, in the effort to govern more effectively, will unfold in a manner that remains largely oblivious to the insecurities and vulnerabilities that may emerge. Each level of analysis illuminates a distinct aspect of the diverse effects that extend beyond the idea of technology as a 'tool' that can simply increase the efficiency of humanitarian actions. Rather, we show how this conception of technology enhances Barnett's analysis of humanitarian governance as a distinct form of power. Adding a conception of technology as agentic similarly calls for attention to these dimensions of power when seeking to understand the mechanisms and processes by which humanitarian technology governance dismantles the boundaries between care and control, emancipation and domination.

A word of caution is, however, important here. These two aspects of emergence and constitutive effects provide a helpful analytical distinction, yet they are closely related: experimentation is both continuous (as Chamayou explains) and a specific occurrence that unfolds within a defined time and space (such as the examples of technology use and looping back effects that co-production invites us to examine). Similarly, in our framework the emergence of constitutive effects is also a continuous process, even as it is possible, at the same time, to study these effects (e.g. the making of digital bodies in the context of humanitarian uses of biometrics) by zooming in on a specific set of practices and technology uses defined in time and space (e.g. Sandvik and Lohne, 2014; Jacobsen, 2015a). Rather, the value of distinguishing between emergence and constitutive effects as two analytically distinct aspects of technology use in humanitarian governance stems from the specific governance challenges that pertain to each. The issue of 'emergence' brings to the surface a set of governance challenges related to the trialling of new technologies in humanitarian contexts and the underlying condition that allows for this (the production of vile bodies). The issue of "constitutive effects' points to the appearance of new challenges stemming from critical questions about how to 'govern' (access to) the data derived from these technology uses. This is not to say that constitutive effects are unimportant in the trial or pilot period. Rather, these constitutive effects become increasingly important with the uptake of new digital technologies and the concomitant generation of data. Similarly, experimentation does not end with the 'initial trial', but the risk of side effects and the importance of protection from these diminishes in importance, while the risk of unintended consequences from constitutive effects, now at a large scale, escalates.

\section{Constitutive effects of technology in humanitarian governance: how care and control intertwine}

To understand the governance implications of humanitarian actors' turn to various new technologies, we must examine both the expectation of technology's promise to improve humanitarian practices and the emergence of potential harmful effects. These effects illuminate how humanitarian technology uses exemplify a form of power that blurs care and control. More specifically, we propose that such a conception can be translated into a framework that calls 
attention to two important dimensions of the politics of humanitarian technology governance: (a) the emergence of new modes of governance and the role of humanitarian actors in this process, and (b) the effects of those technology uses in terms of their continuously unfolding constitutive effects. In doing so we move from thinking about humanitarian governance through technology (with technology as a means to a predefined end-goal or problem) to thinking about governance of technology uses (experimentation) and about governance of that which is being produced (that is data, digital bodies, new forms of vulnerability) in humanitarian contexts. Put differently, this approach to technology adds to Barnett's notion of humanitarian governance an explicit plea for analysing the role of technology, beginning with the assumption that technologies are not simply neutral means by which a predefined end-goal (e.g. improved humanitarian governance) can be pursued. Starting from this co-productionist stance makes it possible to appreciate how an important dimension of contemporary humanitarian technology uses is related to the productive effects and sometimes unforeseen looping effects, such as those related to biometric refugee registration.

\section{From framework to analysis: becoming alert to new challenges of access}

The previous discussion provides a conceptual framework for analysing the use and products of humanitarian technology and their relationship to governance, both the governance of technology in the making and governance of the products of technology, in this case, digitalised humanitarian subjects.

In this section we extend this reconceptualisation of the role of technology in humanitarian governance to a longstanding question in the humanitarian domain, namely that of access. More specifically, we suggest that the above framework enables an appreciation of how a humanitarian turn to digital technology and data cannot simply overcome challenges of access; instead, it also generates new challenges. Two sets of challenges become visible: (a) access to (production of) humanitarian test subjects, and (b) access to (production of) digital refugee bodies/humanitarian population data. Below we present two examples that illustrate the importance of looking beyond an initial and continuously optimistic framing of digital technology as a solution to humanitarian challenges. We do not suggest that drones, biometrics, or the data they generate cannot offer benefits to humanitarian assistance. Rather, the point is how to make sure that potential benefits are not offset by the emergence of new risks and governance issues.

Vile bodies and access to test subjects: experimentation, subordination and exposure to risk In 2002, United Nations High Commissioner for Refugees (UNHCR) used iris scans, for the first time, to register returning Afghan refugees. Iris recognition had not previously been used in such hot and dusty settings. When used under these harsh and challenging conditions, there was a risk that the biometric equipment would fail to enrol or recognise refugees correctly. ${ }^{4} \mathrm{UNHCR}$ therefore referred to this technology use as 'experimental' (UNHCR, 2003). ${ }^{5}$ Since then, agencies have rolled out additional biometric pilot projects in the context of refugee registration and assistance (Jacobsen, 2017). Such trialling of new biometric technology in humanitarian contexts is, however, not limited to the case of refugee registration. As part of a humanitarian endeavour to deliver medical aid, other trials have unfolded, such as the testing of 'a fingerprint-based system to track 
which vaccines children have been given' (Buhrow, 2016, p. 66). These processes subject these bodies to experiments and thus expose them to different forms of risk and insecurity.

Those providing biometric data may or may not fully comprehend the consequences of providing their digital data. This is especially true of those who are not yet included in the digital age; it is equally true of those who, whether by choice or lack of awareness, do not fully grasp the potential harm that may accrue to them. Some of this stems from the risk that biometric data may be accessed by actors with non-humanitarian aims. Not only is this a risk in view of UNHCR's debates with host states over access (Jacobsen, 2016), it grows as the use of biometrics multiplies in a variety of settings bordering humanitarian ones. Biometric registration is, for example, being rolled out in a number of development contexts - notably in a large number of African states-where one dimension of this technology use is about testing the usefulness of biometric registration. This, too, is inseparable from a host of potentially negative side effects. In the Philippines, a computer containing personal biometrics information of Filipino voters was stolen. In addition to such effects, there are also constitutive effects: (a) the constitution of the Filipino population as newly digitally governable and vulnerable, and (b) the constitution of 'success stories' (or the potential for constitution of success stories) to enable broader acceptability and further roll-out of biometric voter registration. Although biometric voter registration is not 'humanitarian' per se, an important point about humanitarian technology governance is the issue of access - and here the growing number of biometric voter databases across Africa deserve attention. Built into the biometric registration of refugees in the Dadaab camp complex in Kenya was a process of cross-matching UNHCR's biometric refugee data with Kenya's national biometric voter register (Jacobsen, 2017). This is only one example of how guarding against access to that which humanitarian technology has made accessible is at the very heart of humanitarian technology governance.

Humanitarian uses of new digital technology need to pay far more attention to the risks of exposing humanitarian subjects - refugees, internally displaced persons (IDPs), and war- or conflict-affected populations - to these new technologies so they do not become test subjects in ways that challenge humanitarian Do No Harm principles (Anderson, 1999; see also Jacobsen, 2015c). A further danger is that humanitarian technologies end up delivering 'perfected' and normatively acceptable technologies of power for the spread of the sovereign state security logic, which often is what creates vulnerable humanitarian subjects in the first place.

\section{Constitutive effects and issues of access to digital humanitarian data}

The increasing availability of digital technologies along with calls for better evidence related to the impact of humanitarian action has created a concomitant growth in the collection and use of data to support humanitarian and development work; everything from biometric data (Jacobsen, 2017) to data collected in support of the 'project cycle'. This includes data, first, to assess needs, then to develop baselines and identify indicators, to regularly monitor project progress, and eventually to assess and evaluate outcomes and the 'success' of projects, whether measured against project goals or impact indicators (i.e., what is the impact of the project on the people or situation). These data, in 
turn, become the basis for reports to donors, their constituents, and representatives, often elected officials and the general public in donor countries.

While humanitarians collect data of all types, some of these data are sensitive, containing personally identifiable information or confidential information about medical records or individuals' political activities. Particularly in conflict or politically fraught locations, these types of data could become problematic for the agencies collecting and storing data and for the individuals whose data are collected and stored. Many humanitarian efforts depend on funding from donor states, and their ability to operate in a host state is based upon consent from host governments. This conundrum has long characterised key elements in the politics of UNHCR's data collection (Betts, Loescher, and Milner, 2012). Adding new digital technology complicates rather than resolves this conundrum, insofar as donor countries and/or host nations may use humanitarian actors' dependence on donor funding or need for host government permission to operate in a given country as leverage to access digitalised (biometric) data. We have seen examples of this in Kenya as well as in Lebanon, where host states have been in dialogue with UNHCR about accessing the biometric data that UNHCR collects and stores about the refugee populations in these countries (Jacobsen, 2016, 2017). Recently, the Malaysian government requested that UNHCR provide access to its data about registered refugees and asylum seekers, in order to 'close loopholes' that might allow individuals sympathetic to Islamic State to enter the country (Goh, 2017). Crucially, allowing access to digitalised biometric refugee data may engender significant risks, such as for the prospect of safe return for refugees who have fled a regime whose post-conflict role is still uncertain (Crowe, 2013).

Beyond donor or host government pressure to share, such data are also potential targets for hackers. The interdependencies of a connected world mean that the ramifications of data hacks extend well beyond any individual or agency, creating new uncertainties, insecurities, and vulnerabilities, particularly for humanitarian actors. The risk of harm is related to the extent to which data are available and accessible, particularly to those with nefarious aims or for those who are vulnerable or unaware. Few have begun to grapple with the potential ramifications of what harm to the digital bodies of vulnerable populations might mean, either conceptually or legally (e.g. Sandvik, 2016; Sandvik and Raymond, 2017). ${ }^{6}$

Whoever owns and controls these data, therefore, possesses leverage and power. In this way the collection or ownership of data have become a new form of governance, amplified by the capacity of digital technologies to amass ever-increasing amounts of data, much of which remains buried in reports or PDF files. As illustrated above, questions of data ownership and sharing have both legal and political bases and consequences.

These access issues stand alongside a range of other data-related exclusivities, such as the privileging of that which can be counted to the neglect of things that do not easily lend themselves to counting (e.g. the number of hours of instruction rather than the quality of education). Quantitative data are easier to collect on mobile devices and faster to aggregate, in contrast to the richer, contextual data that often take longer to collect and analyse. In this way humanitarian 
technologies create new domains of 'humanitarian expertise', requiring internet or mobile connectivity, the ability to use and adapt technologies for humanitarian purposes, as well data collection, analysis, and visualisation (Fast and Waugaman, 2016). In some cases, this becomes another way to marginalise the contextual expertise of national staff (insiders), in contrast to the technical expertise of outsiders (Autesserre, 2014) and yet another way to create hierarchies of humanity in the humanitarian space (Fast, 2014, 2015). Exclusion thus becomes digitally determined, a more modern version of the exclusions that in decades past might have been determined by physical accessibility (living near a road) or position within society (Chambers, 1983).

It is not that humanitarian agencies have ignored these issues. Various UN and international agencies, including UNHCR and International Organization for Migration (IOM), have data protection and privacy policies in place, and the International Committee of the Red Cross, together with the Brussels Privacy Hub, recently released an extensive data protection handbook that addresses many of these issues (Kuner and Marelli (eds.), 2017; Kaspersen and Lindsay-Curtet, 2016). Yet the costs of securing the data that are collected are vast, and the implications for access and protection have not yet been fully analysed or translated into widespread practice.

\section{Consequences}

In this article, we use Barnett's (2013) framework of humanitarian governance and extend it further to address the implications of the humanitarian cyber-age, particularly the use of humanitarian technologies, the data they generate, and the governance challenges that result, whether from unintended and unforeseen consequences of their use or what they produce. In doing so, we call for attention to potential harms and expand the notion of access. Specifically, as a consequence of the humanitarian agencies' collection of sensitive, often uniquely identifiable, and more easily shareable digitalised information (including biometric data), protection is no longer only about ensuring access but increasingly also about denying access. More specifically, it concerns the question of how to deny access to data when this could potentially harm rather than protect the individuals or populations with whom humanitarians work. The use of humanitarian technologies makes possible new domains of information sharing, which in turn create new risks to the digital bodies of humanitarian subjects.

While accessing populations in need of humanitarian assistance continues to represent a significant challenge - with recent examples of Syria, Myanmar, and South Sudan — the argument advanced above is not that this challenge has disappeared. Rather, that it has changed. By analysing humanitarian technology governance, with the increasingly central role that digital technology and data play in a range of humanitarian contexts, another key concern has emerged - a challenge that represents a reversal of the usual conceptualisation of access to assistance or affected populations or their access to services and protection. Instead, this analysis suggests the need to think about access in terms of prevention, and specifically the prevention of access to the digital bodies that arise from the use of technology and data in humanitarian settings. This last dimension is two-fold, in terms of the creation of new test subjects and access to the digital bodies of humanitarian subjects. 
In this way, analysing humanitarian governance helps to identify new challenges and may also, through further research, help to address them. A research agenda on this topic should include additional and detailed explorations of the ways that aid agencies use technologies, the foreseeable and unintended consequences (such as requests for data) of these uses, and how agencies have attempted to address some of these issues. This might encompass field-based data protection strategies, data protection standards, and policies, as well as their implementation, negotiations with host or other governments, litigation, or other strategies. This last element, of practical strategies to mitigate and respond to the challenges that arise from an analysis of humanitarian technology governance, is essential given the real-world implications of this field. Such efforts could help to ensure more effective protection of humanitarian subjects, in terms of access to these populations, their access to assistance, and the prevention of access to their digitalised bodies.

\section{Acknowledgements}

The authors thank the editors of this special issue as well as the two anonymous reviewers for their constructive feedback. 


\section{References}

Abdelnour, S. and A.M. Saeed (2014) 'Technologizing humanitarian space: Darfur advocacy and the rape-stove panacea'. International Political Sociology. 8(2). pp. 145-163.

Agamben, G. (1998) Homo Sacer: Sovereign Power and Bare Life. Stanford University Press, Stanford, CA.

Agier, M. (2010) 'Humanity as an identity and its political effects (a note on camps and humanitarian government)'. Humanity: An International Journal of Human Rights, Humanitarianism, and Development. 1(1). pp. 29-45.

Anderson, M.B. (1999) Do No Harm: How Aid Can Support Peace-or War. Lynne Rienner Publishers, Boulder, CO.

Andersson, R. and F. Weigand (2015) 'Intervention at risk: the vicious cycle of distance and danger in Mali and Afghanistan'. Journal of Intervention and Statebuilding. 9(4). pp. 519-541.

Autesserre, S. (2014) Peaceland: Conflict Resolution and the Everyday Politics of International Intervention. Cambridge University Press, Cambridge.

Barnett, M. (2011). Empire of Humanity: A History of Humanitarianism. Cornell University Press, Ithaca, NY.

Barnett, M.N. (2013) 'Humanitarian governance'. Annual Review of Political Science. 16(1). pp. 379-398.

Bennett, J. (2010) Vibrant Matter: A Political Ecology of Things. Duke University Press, Durham, $\mathrm{NC}$.

Bennett, C., M. Foley, and S. Pantuliano (2016) Time to Let Go: Remaking Humanitarian Action for the Modern Era. Humanitarian Policy Group, Overseas Development Institute, London.

Betts, A., G. Loescher, and J. Milner (eds.) (2012) The United Nations High Commissioner for Refugees (UNHCR): The Politics and Practice of Refugee Protection into the 21st Century. $2^{\text {nd }}$ Edition. Routledge, London.

Buhrow, W.C. (2016) Biometrics in Support of Military Operations: Lessons from the Battlefield. CRC Press, Boca Raton, FL.

Burns, R. (2014) 'Rethinking big data in digital humanitarianism: practices, epistemologies, and social relations'. GeoJournal. 80(4). pp. 477-490.

Chamayou, G. (2008) Les corps vils: expérimenter sur les êtres humains aux XVIIIe et XIXe siècles. Éditions La Découverte, Paris.

Chamayou, G. (2012) Manhunts: A Philosophical History. Princeton University Press, Princeton, NJ.

Chambers, R. (1983) Rural Development: Putting the Last First. Pearson Education Limited, Harlow.

Coole, D. (2013) 'Agentic capacities and capacious historical materialism: thinking with new materialisms in the political sciences'. Millennium Journal of International Relations. 41(3). pp. 451-469.

Crowe, A. (2013) 'Rush to aid Syrians overlooks protecting right to privacy'. [Blog] Privacy International. 30 November. https:/privacyinternational.org/blog/1211/rush-aid-syriansoverlooks-protecting-right-privacy

Duffield, M. (2007) Development, Security and Unending War: Governing the World of Peoples. 
Polity Press, Cambridge.

Duffield, M. (2016) 'The resilience of the ruins: towards a critique of digital humanitarianism'. Resilience - International Policies, Practices and Discourses. 4(3). pp. 147-165.

Fassin, D. (2010) 'Inequality of lives, hierarchies of humanity: Moral commitments and ethical dilemmas of humanitarianism'. In I. Feldman and M. Ticktin (eds.) In the Name of Humanity: The Government of Threat and Care. Duke University Press. Durham, NC. pp. 239-255.

Fast, L. and A. Waugaman (2016) Fighting Ebola with Information: Learning from the Use of Data, Information, and Digital Technologies in the West Africa Ebola Outbreak Response. USAID, Washington, DC.

Fast, L. (2014) Aid in Danger: The Promise and Perils of Humanitarianism. University of Pennsylvania Press, Philadelphia, PA.

Fast, L. (2015) 'Unpacking the principle of humanity: tensions and implications'. International Review of the Red Cross. 97(897-898). pp. 111-131.

Fast, L. (2017) 'Diverging data exploring the epistemologies of data collection and use among those working on and in conflict'. International Peacekeeping. 24(5). pp. 706-732.

Feldman, I. and M. Ticktin (eds.) (2010) In the Name of Humanity: The Government of Threat and Care. Duke University Press, Durham, NC.

Givoni, M. (2016) 'Between micro mappers and missing maps: Digital humanitarianism and the politics of material participation in disaster response'. Environment and Planning D: Society and Space. 34(6). pp. 1025-1043.

Goh, M. (2017) 'Malaysia urges UN refugee agency to share database over Islamic State militant concerns'. Channel NewsAsia. 31 July.

http://www.channelnewsasia.com/news/asiapacific/malaysia-urges-un-refugee-agency-toshare-database-over-islamic-9078300 (last accessed last accessed 19 December 2018)

Graboyes, M. (2011) The Experiment Must Continue: Medical Research and Ethics in East Africa, 1940-2014. Ohio University Press, Athens, OH.

Harvard Humanitarian Initiative (2011) Disaster Relief 2.0: The Future of Information Sharing in Humanitarian Emergencies. UN Foundation and Vodafone Foundation Technology Partnership, Washington, DC and London.

IFRC (2013) World Disasters Report: Focus on Technology and the Future of Humanitarian Action. International Federation of Red Cross and Red Crescent Societies, Geneva.

Jacobsen, K.L. (2015a) 'Experimentation in humanitarian locations: UNHCR and biometric registration of Afghan refugees'. Security Dialogue. 46(2). pp. 144-164.

Jacobsen, K.L. (2015b) The Politics of Humanitarian Technology: Good Intentions, Unintended Consequences and Insecurity. Routledge, London.

Jacobsen, K.L. (2015c) 'Humanitarian technology: revisiting the 'Do No Harm' debate'. [Blog] Humanitarian Practice Network (HPN). http://odihpn.org/blog/humanitarian-technologyrevisiting-the-\%C2\%91do-no-harm\%C2\%92-debate/ (last accessed last accessed 19 December 2018)

Jacobsen, K.L. (2016) 'UNHCR, Accountability and Refugee Biometrics' in Sandvik and Lindskov Jacobsen (eds.) UNHCR and the Struggle for Accountability. Routledge, London. 
Jacobsen, K.L. (2017) 'On humanitarian refugee biometrics and new forms of intervention'. Journal of Intervention and Statebuilding. 11(4). pp. 529-551.

Jasanoff, S. (2005) Designs on Nature: Science and Democracy in Europe and the United States. Princeton University Press, Princeton, NJ.

Jasanoff, S. (2004a) 'The idiom of co-production'. In S. Jasanoff (ed.) States of Knowledge: The Co-Production of Science and Social Order. Routledge, London. pp. 1-12.

Jasanoff, S. (2004b) 'Ordering Knowledge, Ordering Society'. In S. Jasanoff (ed.) States of Knowledge: The Co-Production of Science and Social Order. London/New York: Routledge, 13-45.

Jumbert, K.B. and M.G. Sandvik (eds.) (2017) The Good Drone: "Newness," Technological Optimism, and Technological Fantasies. Routledge, London.

Kaspersen, A. and C. Lindsay-Curtet (2016) 'The digital transformation of the humanitarian sector'. [Blog] Humanitarian Law and Policy. http://blogs.icrc.org/law-andpolicy/2016/12/05/digital-transformation-humanitarian-sector/ (last accessed 12 December 2016).

Kent, R., C. Bennett, A. Donini, and D. Maxwell (2016) Planning from the Future: Is the Humanitarian System Fit for Purpose? Planning from the Future, London and Somerville, MA.

Knox-Clarke, P. (2017) Changing Humanitarian Action? ALNAP Working Paper. ALNAP/Overseas Development Institute, London.

Kuner, C. and M. Marelli (eds.) (2017) Handbook on Data Protection in Humanitarian Action. ICRC and Brussels Privacy Hub, Geneva and Brussels.

Lambert, L. (2013) 'The body as a terrain of experiments: medicine and vile bodies according to Grégoire Chamayou'. The Funambulist Magazine.

https://thefunambulist.net/history/history-the-body-as-a-terrain-of-experiments-medicineand-vile-bodies-according-to-gregoire-chamayou. (last accessed on 20 July 2017)

Latour, B. (1996) 'On actor-network theory. A few clarifications plus more than a few complications'. Soziale welt. 47(4). pp. 369-381.

Lautze, S., A. Raven-Roberts, and T. Erkineh (2009) Humanitarian governance in the new millennium: an Ethiopian case study. HPG Working Paper. Humanitarian Policy Group/Overseas Development Institute, London.

Lester, A. and F. Dussart (2014) Colonization and the Origins of Humanitarian Governance: Protecting Aborigines Across the Nineteenth-Century British Empire. Cambridge University Press, Cambridge.

Malkki, L. (1996) 'Speechless emissaries: refugees, humanitarianism, and dehistoricization'. Cultural Anthropology. 11(3). pp. 377-404

McDonald, S.M. (2016) Ebola: A Big Data Disaster; Privacy, Property, and the Law of Disaster Experimentation. CIS Paper Series, Vol. 1. Centre for Internet \& Society, Bengaluru and Delhi. http://cis-india.org/papers/ebola-a-big-data-disaster (last accessed last accessed 19 December 2018)

Meier, P. (2015) Digital Humanitarians: How Big Data is Changing the Face of Humanitarian Response. Routledge, London. 
Mitchell, K. (2017) 'Education, race and empire: a genealogy of humanitarian governance in the United States'. Transactions of the Institute of British Geographers. 42(3). pp. 349-362.

OCHA (2013) Humanitarianism in the Network Age. Including World Humanitarian Data and Trends 2012. United Nations Office for the Coordination of Humanitarian Affairs, New York, NY. https://www.unocha.org/sites/unocha/files/HINA_0.pdf_llast accessed last accessed 19 December 2018)

Parker, B. (2016) 'Aid's cash revolution: a numbers game. Lebanon leads the way on cash aid for refugees'. IRINnews.org, 2 November. https://www.irinnews.org/feature/2016/11/02/aid'scash-revolution-numbers-game (last accessed last accessed 19 December 2018)

Petryna, A. (2005) 'Ethical variability: drug development and globalizing clinical trials'. American Ethnologist. 32(2). pp. 183-197.

Petryna, A. (2009) When Experiments Travel: Clinical Trials and the Global Search for Human Subjects. Princeton University Press, Princeton, NJ.

Read, R. (2016) 'Tensions in UN information management: security, data and human rights monitoring in Darfur, Sudan'. Journal of Human Rights Practice. 8(1). pp.101-115.

Read, R., B. Taithe, and R. Mac Ginty (2016) 'Data hubris? Humanitarian information systems and the mirage of technology'. Third World Quarterly. 37(8). pp. 1314-1331.

Redfield, P. (2012) 'Bioexpectations: life technologies as humanitarian goods'. Public Culture. 24(1). pp. 157-184.

Sandvik, K.B. (2016) 'The humanitarian cyberspace: shrinking space or an expanding frontier?'. Third World Quarterly. 37(1). pp. 17-32.

Sandvik, K.B. and K. Lohne (2014) 'The rise of the humanitarian drone: giving content to an emerging concept'. Millennium. 43(1). pp. 145-164.

Sandvik, K.B., M.G. Jumbert, J. Karlsrud, and M. Kaufmann (2014) 'Humanitarian technology: a critical research agenda'. International Review of the Red Cross. 96(893). pp. 219-242.

Sandvik, K. and N. Raymond (2017) 'Beyond the protective effect: towards a theory of harm for information communication technologies in mass atrocity response'. Genocide Studies and Prevention. 11(1). pp. 9-24.

Sandvik, K., K. L. Jacobsen, and S. McDonald (2017) "Do no harm: A taxonomy of the challenges of humanitarian experimentation” International Review of the Red Cross, 99:1, 319-344.

Scott-Smith, T. (2015a) 'Control and biopower in contemporary humanitarian aid: the case of supplementary feeding'. Journal of Refugee Studies. 28(1). pp. 21-37.

Scott-Smith, T. (2015b) 'Beyond the "raw" and the "cooked": a history of fortified blended foods'. Disasters. 39(2). pp. 244-260.

Shah, S. (2006) The Body Hunters: Testing New Drugs on the World's Poorest Patients. New Press, New York, NY.

Tomlinson, M., M.J. Rotheram-Borus, L. Swartz, and A.C. Tsai (2013) 'Scaling up mHealth: where is the evidence?'. PLoS Med. 10(2). p. e1001382. DOI:10.1371/journal.pmed.1001382.

UNHCR (2003) 'Iris testing of returning Afghans passes 200,000 mark' https://www.unhcr.org/news/latest/2003/10/3f86b4784/iris-testing-returning-afghanspasses-200000-mark.html (last accessed last accessed 19 December 2018) 


\section{Witjes, N. and P. Olbrich (2015) 'Enabling transparency through technology? Non-governmental satellite imagery analysis of North Korea'. ISIS Summit 4, Vienna.}

\footnotetext{
${ }^{1}$ Adding to this is a parallel literature on the significance of other humanitarian technologies; stoves (Abdelnour and Saeed, 2014) and 'humanitarian goods, presenting themselves as an ethical response to failure on the part of states' (Redfield, 2012, p.158). While not the main focus of this article (as we zoom in on digital technology), it is nonetheless still important to mention, that Abdelnour and Saeed's analysis of the stove draws upon Science and Technology Studies (STS) insights compatible with those presented in this article. Along similar lines, Redfield's analysis, notably his focus on material goods presenting themselves as solutions, is also compatible with a co-productionist framing of how certain technologies come to appear as 'solutions' and on what this implies for how specific social problems are then framed.

${ }^{2}$ See, for example, Graboyes (2011).

${ }^{3}$ Others have used different notions to refer to this production of forms of less valuable life, also in the context of humanitarianism. See, for example, Agamben's notion of 'bare life' and the idea of a secret solidarity between humanitarianism and violent forms of sovereign power that humanitarianism is otherwise seen to guard against (Agamben, 1998). An important difference between Agamben and Chamayou is, however, that Chamayou more explicitly links the production of less valuable life to practices of experimentation and to the exercise of sovereign power.

${ }^{4}$ See Jacobsen (2015a, 2015b) on how such technology failures could potentially translate into humanitarian failures to assist refugees deserving of assistance (according UNHCR's mandate).

${ }^{5}$ The opening of 'experimental iris testing verification centres' along the Afghan-Pakistan border (UNHCR, 2003).

${ }^{6}$ Moves in this direction include the Signal Code (https://signalcode.org) and Brad Smith's, President and Chief Legal Officer at Microsoft, call for a 'digital Geneva Convention' (see https://blogs.microsoft.com/on-the-issues/2017/02/14/need-digital-geneva-convention/). Smith's call would expand the bounds of protection of civilians to digitally produced harm and comes in response to the rise in nation-state cyberattacks.
} 